\title{
Foreign Direct Investment and Economic Growth: Panel Data Analysis
}

\author{
BEGÜM ERDIL ŞAHIN \\ Assistant Professor at İstanbul Kültür University Faculty of Economics and Administrative Sciences \\ Department of Economics \\ Email: b.sahin@iku.edu.tr \\ Tel: +902124984928 \\ DENIZ DILARA DERELI \\ Assistant Professor at İstanbul Kültür University Faculty of Economics and Administrative Sciences \\ Department of Economics \\ Email: d.dereli@iku.edu.tr \\ Tel: +902124984443
}

\begin{abstract}
The aim of this study is to evaluate the relationship between foreign direct investment and economic growth. Although there is no consensus on the relationship between foreign direct investment flows and economic growth in the literature, a growing view in recent years shows that foreign direct investments have contribution on economic growth. These investments act as a main factor for the economic growth of both developed and developing countries. Panel data analysis is used for the empirical study for evaluating the relationship between foreign direct investments and GDP. Data from 14 OECD countries for GDP and foreign direct investments for the 1990-2017 period is used. According to the results of the study, a positive relationship between foreign direct investments and economic growth was identified.
\end{abstract}

Keywords: Foreign Direct Investments, Economic Growth, Panel Data Analysis.

\section{Introduction}

Inadequate capital accumulation is the main obstacle for underdeveloped and developing countries to realize their development. Due to low income and low saving levels, required capital accumulation can not be achieved in order to make investments needed for the structural transformation of economy.

The additional capital created by foreign direct investments increase production capacity and employment, and contribute to modernization of production structure and dynamism. With the increasing competition in the country, the domestic enterprise sector grows. Moreover, transfer of technology and know-how to host country can be realized by foreign direct investments and exports are encouraged. For these reasons countries want to attract foreign direct investments. Because foreign direct investments help capital entry to industries that have the potential to compete on the international scene, the global links of multinational companies make it easier for these countries to reach foreign markets. In addition to direct exports of foreign companies, foreign direct investment can increase exports in the host country by teaching appropriate marketing methods and creating new distribution channels (Bozdağlığlu ve Özpınar, 2011: 40).

In addition to the high profits of investments, which is an important determinant in the flow of foreign capital, transferring the profit obtained in foreign countries to its own country is also an important factor. Another factor in the development of foreign capital is the investment and saving rates of the country. 
International capital inflows finance the deficits of the balance of payments caused by countries' investment and saving imbalances. Developing countries are encouraging foreign capital inflows to overcome the capital shortage they face and contraction of production. Foreign firms are trying to attract foreign direct investments by giving various tax exemptions and incentives as well as market priorities, infrastructure services and even monopoly priorities (Koyuncu, 2010: 57).

Structural bottlenecks in the financing of growth and development in developing countries is both the cause and result of the problem, and the only option for solution is to attract foreign funding to the country (Erdoğan, 2016: 168). As a result, the production of goods and services will increase with the effect of increasing investments, income levels and savings will also increase. In this regard, by creating resources for new investments, production capacities will be increased and economic growth will take place.

In this study, initially the literature on the relationship between direct foreign capital and growth is summarized. Then, the relationship between foreign direct investment and growth in 14 advanced and emerging countries including Turkey are examined by panel data analysis for 1990-2017 period.

\section{Literature Review}

In the literature, there is no consensus in studies related to foreign direct investment and growth relation but positive contribution of foreign direct investment on growth has been found in general. The main studies on foreign direct investment and growth relationship and their findings are as follows;

Lensink and Morrissey (2001) examined the link between foreign direct investment and economic growth in developing counties for 1975-1998 period. According to the sytudy results there has been a consistent finding that foreign direct investment has a positive effect on growth whereas volatility of foreign direct investment has a negative impact.

The study of Campos and Kinoshita (2002) tests the effects of foreign direct investment on growth in 25 Central and Eastern European and former Soviet Union transition countries between 1990 and 1998. According to the main finding of the study, foreign direct investment has a positive and significant impact on economic growth.

In their study Carkovic and Levine (2002) investigated the relationship between economic growth and foreign direct investment for 1960-1995 period and found that the exogenous component of foreign direct investment does not exert a robust, independent influence on growth.

Basu, Chakraborty and Reagle (2003), explored the two-way link between foreign direct investment and growth for a panel of 23 developing countries using a panel cointegration framework. A long-run cointegrating relationship was found between foreign direct investment and GDP after allowing for heterogeneous country effects. The cointegrating vectors reveal a bidirectional causality between GDP and foreign direct investment for more open economies. For relatively closed economies, long-run causality appears unidirectional and runs from GDP to foreign direct investment, implying that growth and foreign direct investment are not mutually reinforcing under restrictive trade and investment regimes.

In his work on 80 countries for 1971-1995 period, Choe (2003) investigated the causality relationship between foreign direct investment and growth and found mutual causality relationship existed among variables.

Li and Liu (2005) used the data for 84 countries for the period of 1970-1999 and investigated the effect of foreign direct investment on economic growth. The method of Panel Data Analysis was used and they found that foreign direct investment affected economic growth positively. Also in the study it was 
determined that foreign direct investments in developing countries increased economic growth indirectly via increases in human capital.

Değer and Emsen (2006) analyzed the foreign direct investment and growth relationship in 27 transition economies for 1990-2002 period by using panel data analysis method, resulting in the fact that foreign direct investment is an important factor for growth.

Hansen and Rand (2006) examined the relationship between foreign direct investment and growth in 31 developing countries for 1970-2000 period through panel cointegration and the Granger causality test. As a result, they found a mutual causality relationship between the variables and reached to the finding that long-term direct foreign investment influences growth.

Apergis, Lyroudi ve Vanvakisids (2007) examined the importance of foreign direct investment on economic growth by using a panel data set for 27 transition economies over the period 1991-2004 as well as the methodology of panel cointegration and causality tests, the empirical findings show that foreign direct investment does exhibit a significant relationship with economic growth.

Ajaga and Nunnenkamp (2008) investigated the long-term causality relationship between foreign direct investment and economic growth using the data for the economy of the United States for the period of 1997-2001 with Johansen Cointegration and Toda-Yamamoto Granger Causality tests. They found that there is a long-term, two-way causality relationship between foreign direct investments and economic growth.

By employing a panel data modelling technique, Batten and Vo (2009) investigated the link between foreign direct investment for 1980-2003 period among 79 countries. The result of the study supports the view that foreign direct investment has a stronger positive impact on economic growth in countries with a higher level of education attainment, openness to international trade and stock market development, and a lower rate of population growth and lower level of risk.

Ağayev (2010) examined the relationship between foreign direct investment and economic growth through 25 transition economies using panel cointegration and panel causality methods. In his study, he found a strong relationship between foreign direct investment and economic growth, and a weak causality relation.

Azman-Saini, Baharumshah, and Law (2010) investigated the systemic link between economic freedom, foreign direct investment and economic growth in a panel of 85 countries. The empirical results, based on the generalized method of moment system estimator, reveal that foreign direct investment by itself has no direct (positive) effect on output growth.

In the study of Özcan and Arı (2010), the factors that effect foreign direct investment are investigated for the 27 OECD countries over the period 1994-2006, with the dynamic panel data analysis method by using GMM forecast technique. At the end of the study, it's seen that GDP growth rate effect foreign direct investment positively.

Şen and Saray (2010), used panal data regression analysis for selected seven countries and Turkey. They found a positive contribution of foreign direct investment on Turkey's growth.

By using panel data test and estimation techniques, Vergil and Karaca (2010) examined the effects of international capital movements on economic growth of developing countries for the period 1980-2005. They found that foreign direct investment and portfolio investment have positive effects, short term capital investment have negative effects on economic growth of countries in the sample. 
In their study Emir and Kutlu (2014) examined the causality relations between GDP and foreign direct investment by the help of Granger Causality Analysis with yearly data for 1983-2012 period for five country including Turkey. As a result, the causality relationship between foreign direct investment and economic growth has been found.

Simionescu (2016), investigated the relationship between economic growth and foreign direct investment inflows in the European Union (EU-28) in the period of the recent economic crisis. Panel data approach and Bayesian techniques were employed to solve the problem of a short set of data (2008-2014). The panel data approaches (panel vector-autoregressive model and Bayesian random effect models) identified a reciprocal and positive relationship between foreign direct investment and economic growth in EU-28 starting with 2008. According to the conclusion of the study reciprocal relationship between economic growth in European Union is found.

Adalı and Yüksel (2017) aimed to determine whether there is a causality relationship between foreign direct investments and economic growth for developing countries. They examined 30 developing countries which have the highest GDP growth rate in 2016. They evaluated annual data of these countries for the periods between 1991 and 2015 with the help of Dumitrescu Hurlin panel causality analysis. The study concluded that there is a causality relationship from foreign direct investments to economic growth. Also a causality relationship from economic growth to foreign direct investment is identified.

Ünsal (2017) comparatively investigated the effects of foreign direct investments on economic growth in the cases of Turkey and other OECD countries. A Time Series Analysis was conducted for Turkey's economy and a Panel Data Analysis was conducted for OECD countries. No long-term or short-term relationship was found between foreign direct investments and economic growth in Turkey's economy. According to the results of Fixed-Effects Regression with Driscoll-Kraay Standard Errors, foreign direct investments affected economic growth in a positive direction in OECD countries.

\section{Panel Data Analysis}

Panel data analysis is a commonly used method that has become widespread in recent years, because of the fact that in this analysis there are two dimensions in a dataset, both horizontal section and time. Using two dimensions together provides utilization of more data and increase in the degree of freedom. Increase in the number of observation adds more variability to measured relation and thus removes the problem of multiple linear correlations (Hsiao, 2003:7).

There are many advantages of using panel data analysis in the estimation of growth models instead of time series and cross-section methods. For example, while only one country or group of countries can be analyzed in the time-series analysis, the panel data analysis enables to examine several countries together. On the other hand, while the cross-section method does not allow control of structural differences between countries, the panel data analysis eliminate this issue (Gülmez and Yardımcıoğlu, 2012:341).

Other advantages of the panel data analyses can be summarized as follows (Gujarati, 2003:638): (i) since data have a sectional data dimension, non-homogeneous effects of sectional-data dimension can be better controlled; (ii) in the panel data, it is easier to identify and measure the affects that cannot be observed only in the sectional data or only in the time series; (iii) the increase in the number of observations also increases the degree of freedom and this increase also minimizes the problem of multiple-linear correlation between independent variables; (iv) since independent variables include both the sectional data and time dimension, more reliable parameter estimates can be obtained. Thus, more reliable results can be reached by the panel data analysis method.

The panel data regression model can be shown as follows (Baltagi, 2011:305). 


$$
y_{i \ddot{u}}=\alpha+X^{\prime}{ }_{i t} \beta+u_{i t}
$$

$i, \mathrm{i}=1,2, \ldots \ldots . N$ represents the section and $t$ represents the time period by $t=1,2, \ldots \ldots . \mathrm{T} . \quad \alpha$ represents amount of data, number of observation; $\beta$ represents $\mathrm{K} \times 1, \mathrm{x}_{\mathrm{it}}$ is the number of related it(th) observation with $\mathrm{K}$ explanatory variables. The $\mathrm{T}$ observation for the first household follows the $\mathrm{T}$ observation for the second household and this continues in this way up to $\mathrm{N}(\mathrm{th})$ household. The error term components can be expressed as follows:

$$
u_{i t}=\mu_{i}+v_{i t}
$$

$\mu_{i}$, indicates certain components of the section and $v_{i t}$ shows the remaining effects. (Baltagi, 2011:306) In other words, it is assumed that $\mu_{\mathrm{i}}$, which is not dependent on time but shows difference from section to section, is called as individual effect, and $v_{i t}$ shows a change both by time and section. According to this, $\mu_{i}$ shows non-observable sectional effect, while $v_{i t}$ represents stochastic error term (Gülmez and Yardımcıŏglu, 2012:341).

In the panel data analysis, there are two alternative methods a "fixed effects model" and "random effects model". According to this, the models in which it is assumed that coefficients change by units or by units and time are called "fixed effects model". The model is, in general, based on that the differences between units can be captured with differences occurring in the fixed term. Hence, in these models, only fixed term shows change and constant term shows differences on cross-sectional basis, not on time (Stock and Watson, 2007: 356).

In the random effects model, it is assumed that the variations due to unit or time are also random like error term. Therefore, the variations occurring depending on unit and time are included in the model as a component of error term. (Asteriou and Hall, 2007: 348)

There are different tests to decide on which to prefer between fixed effects model or random effects model in the selection of panel data model. These are Hausman test, Wald test, F and t tests (Tatoğlu, 2012: 179). One of the commonly used tests is Hausman test and therefore it is preferred in this study. Thus, information only on this test will be shared.

The Hausman test method is based on examining the correlation between unit-specific error term and independent variables. Thus, this test is used to determine whether there is a relation between explanatory variations of the model and unit effects (Greene, 2002:301).

The basic hypothesis of Hausman test in which the random effects estimator applies, tests the degrees of freedom " $\mathrm{k}$ " with the help of statistics complying to $\chi^{2}$ distribution. According to this, the basic hypothesis is that there is no correlation between independent variable and unit effect. And according to the alternative hypothesis, independent variables are correlated with unit effect. In this case, the random effects estimator is deviant and since the difference between both estimators is expected to be large, the fixed effects model should be preferred (Tatoğlu, 2012: 180). As a result of tests conducted in this study, it is decided to use the fixed effects model.

\section{Fixed Effects Model}

The fixed effects model creates a different fixed value for each horizontal sectional unit. It is assumed that the inclination coefficients indicated by $\mathrm{B}$ in the fixed effects model show a variation only between the sectional data or only between the time data or within both data. In other words, when there is a difference between sections in the panel dataset, if there is no time-dependent differentiation, this regression model is named as one-way and section-based fixed effects model. If differentiation occurs only depending on time, such models are named as one-way and time-dependent fixed effects model. If there is a differentiation in 
panel data by both time and section, these models are named as bi-directional fixed effects model (Hsiao; 2003:30).

In the panel data analyses, general indication of the fixed effects model assumes that the differentiation between sections can be seen in the differentiations of fixed terms. Accordingly, below given equation also expresses the general indication of fixed effects models;

$$
Y_{i t}=\alpha+\beta_{1 i t} X_{1 i t}+\ldots+\beta_{k i t} X_{k i t}+e_{i t}
$$

Here, it is assumed that $e_{i t} \approx I I D\left(o, \sigma_{e}^{2}\right)$. In other words, it is assumed that the variance of error terms shows independent and identical distribution in a manner to be equal to zero. Also, each $X_{i t}$ value is independent of $e_{i t}$ value. (Hsiao, 2003:18)

When the primary purpose in the fixed effects model is to estimate the inclination parameters, it is not required to include a shadow variation in the model to show unit effects. In the intra-group estimation method, unit averages are subtracted from time series for each unit to convert the variables. Then, pooled least squares method is applied to the regression generated by converted variables. In the next step, the unit shadow variance coefficients can be estimated by use of group averages of residues. Thus, it is avoided from both shadow variance trap and multicollinearity issue (Tatoğlu, 2012: 86).

\section{Data Set and Model}

The panel data analysis performed in this study covers 14 selected OECD (Organization for Economic Cooperation and Development) countries, including Turkey. In the selection of countries, priority has been given to developed and developing countries with data accessible within time period of $1990-2017$. As direct foreign capital investments and economic growth used in the study, GDP data was obtained from OECD database. In addition, in order to make the data suitable for analysis, their logarithms were taken. Countries included in the analysis are as follows: S.Korea, USA, Mexico, Brazil, France, China, India, Malaysia, the Netherlands, Poland, Singapore, Portugal, England and Turkey.

\section{Panel Data Analysis Results}

In order to enable the selection of appropriate panel data model with direct foreign capital investments and GDP data, firstly an LR test was conducted to see if there is a unit and time effect. According to result of LR test $=841.88(0.000)$ where the unit and time effects are tested together, the probability value of test statistic is $0.00<0.05$, and the hypothesis $H_{0:} \sigma_{\mu}=\sigma_{\lambda}=0$ was rejected and the hypothesis $H_{1:} \sigma_{\mu} \neq \sigma_{\lambda} \neq 0$ was accepted and it was concluded that one of the unit and/or time effects is applicable in the model.

Table 1: Testing of Unit Effect in the Model

\begin{tabular}{|l|c|c|}
\hline Fependent Variable (GDP) & Coefficient & $\begin{array}{c}\text { Test Statistics- } \\
\text { Prob. Value }\end{array}$ \\
\hline Constant & 0.4025801 & $23.56(0.000)$ \\
\hline LR Test & 7.731714 & $37.66(0.000)$ \\
\hline LR Test Results & \multicolumn{2}{|c|}{609.40} \\
\hline LR Test Prob. Value & \multicolumn{2}{|c|}{$(0,000)$} \\
\hline
\end{tabular}

When the test results in Table 1 are examined, according to LR test, the zero hypothesis, indicating that there is no unit effect $\left(\mathrm{H}_{0:} \sigma_{\mu}=0\right)$ was rejected and it was concluded that the unit effect will take place in the said model. Also, it was determined that the zero hypothesis $\left(\mathrm{H}_{0:} \sigma_{\lambda}=0\right)$, indicating that there is no time effect according to LR test was accepted, and that no time effect will take place in the said model. 
In the panel data analysis, the fixed effects model is in general a frequently used and preferred model. However, if the random effects model gives more efficient results than the fixed effects model, then the random effects model should be used. Following the testing of presence of unit and time effects in the model, the Hausman Test was used to decide between the Fixed Effects Model and the Random Effects Model.

Table 2: Hausman Test Results

\begin{tabular}{|c|c|}
\hline Coefficients & FDI \\
\hline Fixed Effect (b) & 0.4001223 \\
\hline Random Effect (B) & 0.4030712 \\
\hline Difference (b-B) & -0.0029489 \\
\hline Sqrt (diag/U_b-U_ß) S.E. & 0.000655 \\
\hline Hausman Test & 20.27 \\
\hline Prob. Value & $(0.000)$ \\
\hline
\end{tabular}

Here, it was tested according to Hausman Test statistic $\mathrm{H}_{\mathrm{o}}$ : Random Effects Model, $\mathrm{H}_{1}$ : Fixed Effects Model hypotheses. As seen in Table 2 as a result of Hausman Test, the probability value of zero hypothesis, indicating the presence of random effects, is below 5\%. This means the rejection of zero hypothesis and acceptance of alternative hypothesis. Accordingly, the one-way (Unit Effect) fixed effects model was preferred in our model. The result is as shown in Table 3 below.

Table 3: Fixed Effects Model Results

\begin{tabular}{|c|c|c|c|c|}
\hline $\begin{array}{l}\text { Dependent Variable } \\
\text { (GDP) }\end{array}$ & Coefficient & Standard Error & Test Statistics & $\begin{array}{c}\text { Probability } \\
\text { Value }\end{array}$ \\
\hline FDI & 0.4001223 & 0.0171431 & 23.34 & 0.000 \\
\hline Constant & 7.756794 & 0.175142 & 44.29 & 0.000 \\
\hline $\mathbf{R}^{2}$ & 0.5910 & 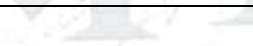 & & 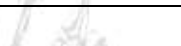 \\
\hline Ftest & $F(13.377)=140.17$ & & & A \\
\hline Prob. Value & $(0.000)$ & & & 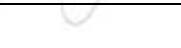 \\
\hline
\end{tabular}

It should be tested whether the preferred model tests the assumptions econometrically. For this reason, tests were conducted to see the presence of variable variance, autocorrelation and correlation between units. By Modified Wald Test, it was tested whether there is a variable variance problem. Accordingly, since the probability value of Wald Test was below $5 \%$ in the analyses conducted, the fixed variance zero hypothesis was rejected and the presence of variable variance in the model was accepted.

And in order to test autocorrelation in the error term, the Bhargava Durbin Test and Baltagi-Wu Locally Best Invariant Test were used. In the Baltagi-Wu Locally Best Invariant Test and Bhargava Durbin Watson test, there is not a critical value to which the test statistics can be compared. However, the fact that the test statistic is less than 2 was interpreted in a way that the autocorrelation is important (Tatoğlu, 2012: 214). When we look at the test statistics in Table 4, it is seen that both test statistics are less than 2. So, it can be said that there is an autocorrelation problem in the error term.

Table 4: Testing Deviation from the Assumptions

\begin{tabular}{|l|l|}
\hline Bhargava Durbin Watson & 0.5350633 \\
\hline Baltagi-WuLBI & 0.64629017 \\
\hline Pesaran's Test & $17.922(0.000)$ \\
\hline
\end{tabular}


Following these tests, the Pesaran test was applied to test whether there is correlation between units in the model. According to Pesaran test, the zero hypothesis indicating that there is no correlation between units was rejected and it was concluded that there is correlation between units.

In the model, the issue of autocorrelation, variable variance and correlation between units was tried to be solved by the method of Driscoll-Kraay for correction of standard errors. When it is considered that the time dimension $\mathrm{T}$ is large, Driscoll and Kraay (1998) show that standard nonparametric time series covariance matrix estimators can be developed to be robust for all forms of spatial and periodic correlation. The methodology of Driscoll and Kraay makes a correction of Newey-West type for horizontal sectional averages. The standard error estimates corrected in this way guarantee the consistency of covariance matrix estimators independently of horizontal section N. Under the hypothesis that there is heteroskedasticity, autocorrelation and correlation between units, a consistent estimate can be made according to $t$ statistics calculated with resistant standard errors in the panel data model (Tatoğlu, 2012: 266-269).

Table 5: The Final Model with Corrected Deviations from the Assumptions

\begin{tabular}{|l|c|c|c|c|}
\hline $\begin{array}{l}\text { Dependent Variable } \\
\text { (GDP) }\end{array}$ & Coefficient & $\begin{array}{c}\text { Driscoll-Kraay } \\
\text { Standard Errors }\end{array}$ & Test Statistics & $\begin{array}{c}\text { Probability } \\
\text { Value }\end{array}$ \\
\hline FDI & 0.4001223 & 0.033033 & 12.11 & 0.000 \\
\hline Constant & 70756794 & 0.3159576 & 24.55 & 0.000 \\
\hline $\mathbf{R}^{2}$ & 0.5910 & & \\
\hline Ftest & $146.72(0.000)$ & \multicolumn{3}{|l}{} \\
\hline
\end{tabular}

According to the results of final model in which the assumptions in Table 5 are corrected, the explanatory power of independent variable to dependent variable is around $60 \%$. That is, $60 \%$ of variance in GDP can be explained by variance in the direct foreign capital investments apparent in the regression model. In this equation, the effect of independent variable on economic growth was realized in line with the expectations. It is also seen that the variables are statistically meaningful. According to the findings obtained from the analysis, there is a positive relation between the direct foreign capital investments and economic growth. $1 \%$ rise in the direct foreign capital investments increases GDP by approximately $0.40 \%$.

\section{Conclusion}

With the impact of globalization and the liberalization of capital movements, significant increases in capital flows have occurred between countries. In this process, foreign direct investment, especially in foreign countries, has begun to gain importance, such as the establishment of a new plant, the purchase of an existing company or the increase of its capital. Foreign direct investments contribute to economic growth by contributing to the resolution of the inadequacy problem of the host country or capital accumulation. On the other hand, foreign capital brings in the advanced knowledge of business and production technology.

The basis of empirical work on foreign direct investment and economic growth is based on neo-classical growth models and new internal growth theories that consider long-term growth which take into account the belief that increased investments and the efficiency of these investments contribute to the economic growth of countries. While there is no complete consensus among the empirical studies, some studies have found a negative relationship between FDI and economic growth, while others have found no relationship between the two. However, in general, foreign direct investment is expected to contribute to economic growth, as it will lead to an increase in the investments of the destination country.

In this study, the relationship between foreign direct investment and economic growth, using panel data analysis method for 14 OECD member countries (S.Korea, USA, Mexico, Brazil, France, China, India, Malaysia, the Netherlands, Poland, Singapore, Portugal, England and Turkey) was analyzed. In the model, when the relation between foreign direct investment and GDP is examined, data of GDP and FDI investments related to 1990-2017 period are utilized. As a result, considering the general conclusions for all 
countries, $1 \%$ increase in foreign direct investment has increased GDP by $0.40 \%$. In other words, there is a positive relationship between foreign direct investment and economic growth in the model.

Foreign direct investment is important in terms of development strategies of developed and developing countries. Countries need to focus on incentive policies for these investments and should be in the position of investable country, to support their sustainable economic growth targets. Undoubtedly, the fact of a country being investable is closely related with the market access conditions and competitive production opportunities. For this reason, the advantages provided in the policies for these investments, will have an impact on the FDI attracting potential and economic growth of that country.

\section{References}

Adalı, Z., \& Yüksel, S. (2017). Causality Relationship Between Foreign Direct Investments and Economic Improvement for Developing Economies. Marmara Journal of Economics, 1(2), 109-118.

Ajaga, E., \& Nunnenkamp, P. (2008). Inward FDI, Value Added and Employment in US States: A Panel Cointegration Approach. Aussenwirtschaft, 63(4), 347.

Ajaga, E., \& Nunnenkamp, P. (2008). Inward FDI, Value Added and Employment in US States: A Panel Cointegration Approach. Kiel Institute for the World Economy, Kiel Working Papers 1420, 1-22.

Ağayev, S. (2010). Doğrudan Yabancı Sermaye Yatırımları ve Ekonomik Büyüme İlişkisi: Geçiş Ekonomileri Örneğinde Panel Eştümleşme ve Panel Nedensellik Analizleri. Gazi Üniversitesi Íktisadi ve İdari Bilimler Fakültesi Dergisi, 12(1), 159-184.

Asteriou, D., \& Hall, S. (2007). Applied Econometrics: A Modern Approach Using Eviews and Microfit. New York: Palgrave Macmillian.

Apergis, N., Lyroudi, K., \& Vanvakisids, A. (2007). The Relationship Between Foreign Direct Investment and Economic Growth: Evidence from Transitional Countries. Transition Studies Review, 15(1), 3751.

Azman-Saini, W.N.W., Baharumshah, A.Z., \& Law, S.H. (2010). Foreign Direct Investment, Economic Freedom and Economic Growth: International Evidence. Economic Modelling, 27,1079-1089.

Baltagi, B.H. (2011). Econometrics. New York: Springer, Fifth Edition.

Batten, J.A., \& Vo, X.V. (2009). An Analysis of The Relationship Between Foreign Direct Investment and Economic Growth. Applied Economics, 41(13), 1621-1641.

Basu, P., Chakraborty C. \& Reagle D. (2003). Liberalization, FDI, and Growth in Developing Countries: A Panel Cointegration Approach. Economic Inquiry, 41 (3): 510-516.

Bozdağlığlu, E.Y., \& Özpınar, Ö. (2011). Türkiye’ye Gelen Doğrudan Yabancı Yatırımların Türkiye'nin İhracat Performansına Etkilerinin VAR Yöntemi ile Tahmini. Dokuz Eylül Üniversitesi Sosyal Bilimler Enstitüsü Dergisi, 13(3), 39-63.

Choe, J.I. (2003). Do Foreign Direct Investment and Gross Domestic Investment Promote Economic Growth?. Review of Development Economics, 7(1): 44-57.

Campos N.F., \& Kinoshita, Y. (2002). Foreign Direct Investment as Technology Transferred: Some Panel Evidence From The Transition Economies. William Davidson Institude Working Paper, 438, 1-35.

Carkovic, M., \& Levine, R. (2002). Does Foreign Direct Investment Accelerate Economic Growth? Financial Globalization: A Blessing or a Curse. World Bank Conference, Financial Globalization: A Blessing or a Curse, 1-22.

Değer, M.K., \& Emsen, Ö.S. (2006). Geçiş Ekonomilerinde Doğrudan Yabancı Sermaye Yatırımları ve Ekonomik Büyüme İlişkileri: Panel Veri Analizleri (1990-2002). Cumhuriyet Üniversitesi İktisadi ve Idari Bilimler Dergisi, 7(2), 121-137.

Emir, M., \& Kutlu, M. (2014). Gelişmekte Olan Ülkelerde Doğrudan Yabancı Yatırımlar ile Ekonomik Büyüme İlişkisi. Journal of Economics, Finance and Accouting, 1(1), 38-45.

Erdoğan, A. (2016). Gelişmekte Olan Ülkelerde Doğrudan Yabancı Sermaye Yatırımları ve Türkiye Örneği. Ankara: Nobel Yayıncılık.

Greene, W.H. (2002). Econometric Analysis. New Jersey: Prentice Hall, Fifth Edition. 
Gujarati, D. (2003). Basic Econometric. USA: McGraw Hill, Fourth Edition.

Gülmez, A., \& Yardımcıoğlu, F. (2012). OECD Ülkelerinde Ar-Ge Harcamaları ve Ekonomik Büyüme İlişkisi: Panel Eşbütünleşme ve Panel Nedensellik Analizi (1990-2010). Maliye Dergisi, 163, 335-353.

Hansen, H., \& Rand, J. (2006). On The Causal Links Between FDI and Growth in Developing Countries. Institute of Economics, University of Copenhagen and Development Economics Research Group, Discussions Papers, 1-21.

Hsiao, C. (2003). Analysis of Panel Data. United Kingdom: Cambridge University.

Koyuncu, F.T. (2010). Türkiye'de Seçilmiş Makroekonomik Değişkenlerin Doğrudan Yabancı Sermaye Yatırımları Üzerindeki Etkisinin Yapısal VAR Analizi: 1990-2009 Dönemi. Ekonomi Bilimleri Dergisi, 2(1), 55-62.

Lensink, R., \& Morrissey, O. (2001). Foreign Direct Investment: Flows, Volatility and Growth in Developing Countries (Research Report 01E16). Groningen: University of Groningen, Research Institute Systems, Organisations and Management.

Li, X., \& Liu, X. (2005). Foreign Direct Investment and Economic Growth: an Increasingly Endogenous Relationship. World Development, 33(3), 393- 407.

Özcan, B., \& Arı, A. (2010). Doğrudan Yabancı Yatırımların Belirleyicileri Üzerine Bir Analiz: OECD Örneği. İstanbul Üniversitesi İktisat Fakültesi Ekonometri ve İstatistik Dergisi, 12, 65-88.

Simionescu, M. (2016). The Relation Between Economic Growth and Foreign Direct Investment During The Economic Crisis in European Union. Journal of Economics and Business, 34(1), 187-213.

Stock, J.H., \& Watson, M.W. (2007). Introduction to Econometrics. Boston: Pearson Education Inc.

Şen, A., \& Saray, M.O. (2010). Türkiye'de Doğrudan Yabancı Sermaye Yatırımlarının Ekonomik Büyümeye Etkisi: Panel Veri Analizi. Akademik Araştırmalar ve Çalışmalar Dergisi, Prof. Dr. Aleaddin Yavaşça Özel Sayısı, 22-30.

Tatoğlu, F. Y. (2012). Panel Veri Ekonometrisi. İstanbul: Beta Yayınları.

Ünsal, M.E. (2017). FDI and Economic Growth: Comparative Analyses Between Turkey and The Other OECD Countries. Journal of Current Researches on Business and Economics, 7(2), 207-2016.

Vergil, H., \& Karaca, C. (2010). Gelişmekte Olan Ülkelere Yönelik Uluslararası Sermaye Hareketlerinin Ekonomik Büyüme Üzerindeki Etkisi: Panel Veri Analizi. Ege Akademik Bakış, 10(4), 1207-1216. 